\title{
NUTRITIONAL DEFICIENCY AND RESISTANCE TO INFECTION
}

\section{THE EFFECT OF CALORIC AND PROTEIN DEFICIENCY ON THE SUSCEPTIBILITY OF RATS AND MICE TO INFECTION WITH SALMONELLA TYPHI MURIUM*}

\author{
By K. GUGGENHEIM And EDITH BUECHLER, Department of Hygiene, and \\ Bacteriology, The Hebrew University, Jerusalem
}

In a previous publication (Kligler, Guggenheim \& Henig, 1945) it was shown that rats and mice on a diet deficient in vitamin A show a loss of resistance to infection by Salmonella. Rats allowed vitamin A exhibit a similar loss of resistance when their food intake is reduced to that of the vitamin A-deficient rats. It is, therefore, proper to inquire whether the lowered resistance of rats on a vitamin A-free diet is due to specific protein deficiency or to a general caloric deficiency. To elucidate this point the experiments reported below, which deal with the separate effects of caloric and protein deficiencies on the susceptibility of rats and mice to infection by Salmonella, were performed.

\section{METHODS}

The rats and mice were taken from the laboratory breeding stock after weaning. The diets employed were of the following composition:

Rice flour

Rice starch

Casein (alcohol extracted)

Olive oil

Dried yeast

Salt mixture

Protein content

Vitamin B supplement* strain of Salmonella, diluted 1 : 10 with milk. Three days later the animals were killed. Cultures were made from mesenteric glands, liver and spleen.

\section{RESULTS}

\section{Experimental infection of rats}

Exp. 1. In previous experiments, young rats on vitamin A-free diet for a period of 5 weeks, i.e. until they had ceased to grow, consumed about $80 \%$ as much food as animals given adequate amounts of vitamin $A$. In an initial period of 2 weeks both the control group and the vitamin A. deficient group consumed about the same amount of food; from the third week onwards the group which was deprived of vitamin A took increasingly less food than the control. In the fifth week of the experiment the food intake of the control group was double that of the vitamin A-deficient group. Taking the intake of the second week as $100 \%$,

\begin{tabular}{|c|c|c|c|c|}
\hline & $\begin{array}{l}\text { Standard } \\
\text { diet }\end{array}$ & $\begin{array}{c}\text { High-protein } \\
\text { diet }\end{array}$ & $\begin{array}{c}\text { Low-protein } \\
\text { diet }\end{array}$ & $\begin{array}{l}\text { Protein-free } \\
\text { supplement }\end{array}$ \\
\hline Rice flour & 66 & 53 & 73 & - \\
\hline Rice starch & 一 & - & 一 & 87 \\
\hline Casein (alcohol extracted) & 13 & 26 & 6 & - \\
\hline Olive oil & 10 & 10 & 10 & 10 \\
\hline Dried yeast & 8 & 8 & 8 & 一 \\
\hline Salt mixture & 3 & 3 & 3 & 3 \\
\hline Protein content & $22 \%$ & $34 \%$ & $15 \%$ & $0 \%$ \\
\hline Vitamin B supplement* & None & None & None & Given \\
\hline
\end{tabular}

* $0.1 \mathrm{mg}$. thiamine, $0.2 \mathrm{mg}$. riboflavin, $0.1 \mathrm{mg}$. pyridoxin, $1.6 \mathrm{mg}$. calcium pantothenate, and $100 \mathrm{mg}$. choline chloride, added to $100 \mathrm{~g}$. protein-free supplement.

Rats received in addition $4 \mathrm{i} . \mathrm{u}$. vitamin $\mathrm{D}$ each twice weekly; mice received one-half of this amount. All rats, except those of group B in Exp. 1, were also given $100 \mathrm{i.u}$. vitamin $\mathrm{A}$ each twice weekly; the mice received one-half of this amount.

The strain of $S$. typhi murium was that used in the earlier experiments. After the rats were 5 (or 10) weeks on the test diets, they were infected per os with 0.1 c.c. of a $24 \mathrm{hr}$. broth culture of the above

* These studies were supported by a grant from the Palestine Endowment Fund, New York. food intake of rats on vitamin A-free diet is in the third week of the experiment $103 \%$, in the fourth $87 \%$ and in the fifth $62 \%$. In a typical case the controls consumed per day per rat $6 \cdot 8 \mathrm{~g}$. of food in the first week, $7 \cdot 5 \mathrm{~g}$. in the second, $8 \cdot 1 \mathrm{~g}$. in the third, 8.4 g. in the fourth and $8.7 \mathrm{~g}$. in the fifth week of the experiment; the corresponding figures for the vitamin A-free group were $6 \cdot 9,7 \cdot 4,7 \cdot 5,6 \cdot 6$ and $4.4 \mathrm{~g}$. Progressive decline of the daily food intake is thus a feature of A-avitaminosis. An experiment was performed to find out whether a decrease of the food consumption by $20 \%$ from the outset of 
an experiment, or equivalent restriction of total intake, imposed progressively, leads to a lowering of the susceptibility of rats to Salmonella infection.

Four groups of male rats, each of thirty animals, were fed as follows: A, standard diet ad libitum supplemented with vitamin $\mathbf{A} ; \mathrm{B}$, as $\mathbf{A}$, but without supplement of vitamin $\mathrm{A}$; $\mathrm{C}$, as $\mathrm{A}$, but adjusted daily in amount, so as to conform to the intake of group B on the day before; D, as A in composition, but reduced in amount by $20 \%$ and with supplement of vitamin A. Groups $\mathrm{C}$ and $\mathrm{D}$ consumed the same total amounts of food but differed from one level of both groups was the same during the 5 weeks' period of the experiment. Group D, restricted from the beginning of the experiment to $80 \%$ of the total amount of food consumed by group A, was not rendered more highly susceptible to Salmonella infection by this restriction; on the other hand, group C, whose food intake was gradually lowered, showed a relatively increased measure of susceptibility. In this type of short-term test, therefore, the factor determinant of increased susceptibility is not the restriction of the food intake per se but the gradual manner of its imposition.

Table 1. Relative susceptibility to Salmonella typhi murium infection of rats on specified diets

A, standard diet, ad libitum, supplemented with vitamin A.

B, as A, but without supplement of vitamin A.

C, as A, but adjusted daily in amount, so as to conform to the intake of group B on the day before, and with supplement of vitamin A.

D, as A in composition, but reduced in amount by $20 \%$ and with supplement of vitamin $A$.

Experimental period: 5 weeks.

$\begin{array}{cccccrrrr}\begin{array}{c}\text { Experi- } \\ \text { mental } \\ \text { group }\end{array} & \begin{array}{c}\text { No. of } \\ \text { rats }\end{array} & \overbrace{\begin{array}{c}\text { At start } \\ \text { of exp. }\end{array}}^{\text {Weight in g. }} \begin{array}{c}\text { At time of } \\ \text { infection }\end{array} & \begin{array}{c}\text { No. } \\ \text { infected }\end{array} & \text { Liver } & \text { Spleen } & \begin{array}{c}\text { Liver and Mesenteric } \\ \text { spleen }\end{array} \\ \text { A } & 30 & 36 & 120 & 17 & 3 & 0 & 0 & 16 \\ \text { B } & 30 & 36 & 76 & 29 & 16 & 15 & 13 & 29 \\ \text { C } & 30 & 36 & 86 & 27 & 17 & 17 & 14 & 25 \\ \text { D } & 30 & 36 & 101 & 18 & 5 & 2 & 2 & 16\end{array}$

Table 2. Relative susceptibility to Salmonella typhi murium infection of rats on specified diets

A, standard diet, ad libitum.

B, standard diet, restricted in amount to the level of the food intake of the vitamin A-free group (cf. Table 1). C, high-protein diet, restricted in amount to the level of intake of standard diet by B.

Experimental period: 5 weeks.

\begin{tabular}{|c|c|c|c|c|c|c|c|c|}
\hline \multirow{2}{*}{$\begin{array}{l}\text { Experi- } \\
\text { mental } \\
\text { group }\end{array}$} & \multirow[b]{2}{*}{$\begin{array}{l}\text { No. of } \\
\text { rats }\end{array}$} & \multicolumn{2}{|c|}{ Weight in g. } & \multirow[b]{2}{*}{$\begin{array}{c}\text { No. } \\
\text { infected }\end{array}$} & \multicolumn{4}{|c|}{ No. of rats with infections in } \\
\hline & & $\begin{array}{l}\text { At start } \\
\text { of exp. }\end{array}$ & $\begin{array}{l}\text { At time of } \\
\text { infection }\end{array}$ & & Liver & Spleen & $\begin{array}{c}\text { Liver and } \\
\text { spleen }\end{array}$ & $\begin{array}{c}\text { Mesenteric } \\
\text { glands }\end{array}$ \\
\hline $\mathbf{A}$ & 30 & 36 & 107 & 19 & 6 & 6 & 3 & 16 \\
\hline $\mathbf{B}$ & 30 & 36 & 82 & 27 & 22 & 20 & 19 & 27 \\
\hline $\mathbf{C}$ & 30 & 36 & 88 & 29 & 21 & 19 & 19 & 28 \\
\hline
\end{tabular}

another in the manner of the distribution of this total intake. At the end of 5 weeks, growth in the vitamin A-free group ceased. The results of the infection susceptibility trial performed at this time are given in Table 1. This table reaffirms earlier findings (Kligler et al. 1945), viz. (a) that rats in a state of A-avitaminosis are more susceptible to oral infection with Salmonella than normally fed controls, and $(b)$ that rats paired fed with the avitaminotic group but allowed vitamin A are equally susceptible with A-avitaminotic rats to Salmonella infection. The table shows also that there is a marked difference in susceptibility to infection between groups C and D, despite the fact that the food intake
Exp. 2. The effect noted above of gradually imposed food restriction was not affected by increase of the relative protein content of the diet. In the test of this conclusion, three groups of male rats were fed as follows: A, standard diet, ad libitum; $B$, standard diet, restricted in amount to the level of the food intake of the vitamin A-free group (cf. Exp. 1); C, high-protein diet, restricted in amount to the level of intake of standard diet by B. The daily ration of $\mathrm{C}$ was gradually reduced, but all in all $\mathbf{C}$ received considerably more protein than $A$. The results of a susceptibility trial at the end of 5 weeks are shown in Table 2. This table demonstrates that the susceptibility of group $C$ was not 
lower than that of group B. The high-protein content of the diet is apparently unable to offset the deleterious effect of the gradually imposed restriction.

Exp. 3. Less protein in a diet restricted in amount ( $80 \%$ of the normal) failed in 5 weeks to augment the susceptibility of rats to infection by Salmonella. In the test of this conclusion three groups of male rats were fed as follows : A, standard diet, ad libitum; B, standard diet, adjusted to $80 \%$ of the consumption of $A$ on the foregoing day; C, low-protein diet, adjusted daily to the level of the ration of $B$. The results of the susceptibility trial are given in Table 3. This table shows that calories as $\mathbf{A}$. The results of the susceptibility trial, performed after 5 weeks, are given in Table 4. As may be seen from the figures shown in this table, group $\mathrm{C}$ was more susceptible to infection than group $A$ and less susceptible to infection than group B. In other words, supplementation of calories in a diet progressively diminished as regards the daily caloric and protein ration improves the resistance of the animals but does not restore it to normal. The effect of progressive restriction in caloric intake accounts, therefore, but partially for the increase of the susceptibility to infection observed in previous experiments. The conclusion is, therefore, strengthened that loss of resistance

Table 3. Relative susceptibility to Salmonella typhi murium infection of rats on specified diets

A, standard diet, ad libitum.

$\mathrm{B}$, standard diet, adjusted to $80 \%$ of the consumption of $\mathrm{A}$ on the foregoing day.

$\mathrm{C}$, low-protein diet, adjusted daily to the level of the ration of $\mathbf{B}$.

Experimental period: 5 weeks.

\begin{tabular}{|c|c|c|c|c|c|c|c|c|}
\hline \multirow{2}{*}{$\begin{array}{c}\text { Experi- } \\
\text { mental } \\
\text { group }\end{array}$} & \multirow[b]{2}{*}{$\begin{array}{l}\text { No. of } \\
\text { rats }\end{array}$} & \multicolumn{2}{|c|}{ Weight in $\mathrm{g}$. } & \multirow[b]{2}{*}{$\begin{array}{c}\text { No. } \\
\text { infected }\end{array}$} & \multicolumn{4}{|c|}{ No. of rats with infections in } \\
\hline & & $\begin{array}{l}\text { At start } \\
\text { of exp. }\end{array}$ & $\begin{array}{l}\text { At time of } \\
\text { infection }\end{array}$ & & Liver & Spleen & $\begin{array}{l}\text { Liver and } \\
\text { spleen }\end{array}$ & $\begin{array}{l}\text { Mesenteric } \\
\text { glands }\end{array}$ \\
\hline $\mathbf{A}$ & 40 & 36 & 104 & 12 & 1 & 0 & 0 & 12 \\
\hline B & 40 & 36 & 92 & 11 & 0 & 1 & 0 & 11 \\
\hline C & 40 & 36 & 83 & 9 & 1 & 1 & 1 & 9 \\
\hline
\end{tabular}

Table 4. Relative susceptibility to Salmonella typhi murium infection of rats on specified diets

A, standard diet, ad libitum.

$\mathbf{B}$, as $\mathbf{A}$, but restricted progressively in amount.

C, standard diet in amount as group B and protein-free supplement, ad libitum.

Experimental period: 5 weeks.

\begin{tabular}{|c|c|c|c|c|c|c|c|c|}
\hline \multirow{2}{*}{$\begin{array}{c}\text { Experi- } \\
\text { mental } \\
\text { group }\end{array}$} & \multirow[b]{2}{*}{$\begin{array}{l}\text { No. of } \\
\text { rats }\end{array}$} & \multicolumn{2}{|c|}{ Weight in g. } & \multirow[b]{2}{*}{$\begin{array}{c}\text { No. } \\
\text { infected }\end{array}$} & \multicolumn{4}{|c|}{ No. of rats with infections in } \\
\hline & & $\begin{array}{l}\text { At start } \\
\text { of exp. }\end{array}$ & $\begin{array}{l}\text { At time of } \\
\text { infection }\end{array}$ & & Liver & Spleen & $\begin{array}{l}\text { Liver and } \\
\text { spleen }\end{array}$ & $\begin{array}{l}\text { Mesenteric } \\
\text { glands }\end{array}$ \\
\hline A & 40 & 36 & 119 & 18 & 4 & 4 & 2 & 16 \\
\hline B & 40 & 36 & 87 & 34 & 22 & 14 & 8 & 32 \\
\hline $\mathrm{C}$ & 40 & 36 & 110 & 26 & 7 & 7 & 2 & 24 \\
\hline
\end{tabular}

susceptibility to Salmonella infection is not augmented when the protein content of the restricted ration is lowered to $15 \%$.

Exp. 4. The question arises whether the effect of gradually restricted food intake on susceptibility is related specifically to a change of the protein intake. Exps. 4 and 5 were performed to clarify this point. Exp. 4 shows the effect of caloric restriction. In this experiment three groups of forty male rats each were given the following diets: A, standard diet, ad libitum; B, diet as A but restricted progressively in amount (cf. the previous experiment); $\mathrm{C}$, standard diet in amount as group $\mathrm{B}$ and proteinfree supplement ad libitum; $C$ received, therefore, no more protein than $B$ and about the same amount of following gradual restriction of food consumption is brought about by the lowering of the intake of protein as well as of calories. Exp. 5 is designed to test this conclusion.

Exp. 5. In this experiment three groups of forty male rats each were fed as follows: A, standard diet, ad libitum; $\mathrm{B}$, the same diet gradually restricted in amount, as described; $\mathrm{C}$, in amount as group B, but adjusted as to protein level by variation of the casein percentage (with compensating variation of the rice flour content) in conformity with the level of the protein consumption of $\mathbf{A}$ on the foregoing day. Group $\mathrm{C}$ received, therefore, the same amount of calories as group B and the same amount of protein as group A. The results of the 
susceptibility trial, performed after 5 weeks, are shown in Table 5. The table shows, in conformity with Exp. 4, that simultaneous gradual restriction of both caloric and protein intake leads to a marked loss of resistance towards infection. In such a feeding regimen, supplementation with protein not only fails to reduce but actually enhances the susceptibility. The experiments suggest, therefore, that in a feeding system involving gradual restriction of the protein supply caloric supplementation leads to an alleviation of the injury to resistance; conversely, in a feeding system involving gradual restriction of the caloric supply protein supplementation augments the lowering of the resistance. from Table 6, prolonged maintenance on a restricted diet leads to a lowering of the resistance to infection. The diminution in resistance is related to the degree of the restriction of the intake, C (60\% of normal food intake) showing a higher susceptibility than B (75\% of normal food intake). It is noteworthy that moderate restriction of food intake (group B) causes a greater lowering of resistance in 10 weeks than in 5 weeks (cf. Exp. 1).

\section{Observations on experimental epidemics in mice}

It could be demonstrated previously that Salmonella epidemics in mice populations can be

Table 5. Relative susceptibility to Salmonella typhi murium infection of rats on specified diets

A, standard diet, ad libitum.

$B$, as $A$, but restricted progressively in amount.

$\mathrm{C}$, in amount as $\mathrm{B}$, but adjusted in protein level in conformity with the level of the protein consumption of $\mathrm{A}$. Experimental period: 5 weeks.

\begin{tabular}{|c|c|c|c|c|c|c|c|c|}
\hline \multirow{2}{*}{$\begin{array}{l}\text { Experi- } \\
\text { mental } \\
\text { group }\end{array}$} & \multirow[b]{2}{*}{$\begin{array}{c}\text { No. of } \\
\text { rats }\end{array}$} & \multicolumn{2}{|c|}{ Weight in g. } & \multirow[b]{2}{*}{$\begin{array}{c}\text { No. } \\
\text { infected }\end{array}$} & \multicolumn{4}{|c|}{ No. of rats with infections in } \\
\hline & & $\begin{array}{l}\text { At start } \\
\text { of exp. }\end{array}$ & $\begin{array}{l}\text { At time of } \\
\text { infection }\end{array}$ & & Liver & Spleen & $\begin{array}{l}\text { Liver and } \\
\text { spleen }\end{array}$ & $\begin{array}{c}\text { Mesenteric } \\
\text { glands }\end{array}$ \\
\hline A & 40 & 34 & 108 & 8 & 1 & 1 & 0 & 8 \\
\hline B & 40 & 34 & 81 & 20 & 10 & 8 & 8 & 16 \\
\hline $\mathrm{C}$ & 40 & 34 & 85 & 28 & 14 & 18 & 12 & 18 \\
\hline
\end{tabular}

Table 6. Relative susceptibility to Salmonella typhi murium infection of rats on specified diets

A, standard diet, ad libitum.

B, standard diet, $75 \%$ of the amount of food consumed by A. C, standard diet, $60 \%$ of the amount of food consumed by A. Experimental period: 10 weeks.

$\begin{array}{ccccccccc}\begin{array}{c}\text { Experi- } \\ \text { mental }\end{array} & \begin{array}{c}\text { No. of } \\ \text { rats }\end{array} & \overbrace{\begin{array}{c}\text { At start } \\ \text { of exp. }\end{array}}^{\text {At time of }} \begin{array}{c}\text { Weight in g. } \\ \text { infection }\end{array} & \begin{array}{c}\text { No. } \\ \text { infected }\end{array} & \text { Liver } & \text { Spleen } & \begin{array}{c}\text { Liver and Mesenteric } \\ \text { spleen }\end{array} \\ \text { A } & 30 & 35 & 184 & 8 & 0 & 0 & 0 & 8 \\ \text { B } & 30 & 36 & 135 & 17 & 6 & 6 & 4 & 17 \\ \text { C } & 30 & 36 & 111 & 22 & 12 & 9 & 9 & 21\end{array}$

Exp. 6. As shown in Exp. 1 restriction of the food intake for a period of 5 weeks to $80 \%$ of the consumption of a control group has no appreciable effect on the infection susceptibility as determined at the end of this period. In a further experiment an attempt was made to ascertain the effect on the infection susceptibility of equal or greater restriction of food intake during 10 weeks. Three groups of rats, each of thirty males, were kept for 10 weeks on standard diet. Group A received the diet ad libitum; groups $\mathrm{B}$ and $\mathrm{C}$ received, respectively, 75 and $60 \%$ of the amount of food consumed by group A. The results of the susceptibility trial, at the end of 10 weeks, are shown in Table 6 . As can be seen employed as an indicator of the relationship of nutritional factors to infection susceptibility. In our experiments we showed that deficiency of riboflavin (Kligler, Guggenheim \& Buechler, 1944), biotin (Kligler, Guggenheim \& Herrnheiser, 1946), or thiamine (Guggenheim \& Buechler, 1946) diminishes the resistance of mice populations to the spread of Salmonella epidemics, the degree of the diminution being related to the severity of the deficiency. In continuation of this work we studied the effect of food restriction on experimental Salmonella epidemics in mice, and in particular the effect on the course of these epidemics of caloric and protein deficiency. 
In the first experiment of this series 4-week-old litter-mates were taken directly from the mothers and divided into three groups, each group comprising ninety-four mice. Group A received standard diet ad libitum, B received standard diet but only $60 \%$ of the amount consumed by $\mathrm{A}$; $\mathrm{C}$ received standard diet in the same amount as B and additionally protein-free supplement ad libitum. Group $\mathrm{C}$ received, therefore, roughly as many calories as $\mathbf{A}$ and the same amount of protein as B. The groups were housed in six cages, with 15-16 mice per cage. At the end of 2 weeks a single mouse in each cage was infected per os with 0.05 c.c. of a $24 \mathrm{hr}$. broth follows: A and B were fed as had been A and B in the foregoing experiment; $D$ received a diet high in protein and equal in total amount to that of group B. Group D received, therefore, the same amount of protein as group $A$, and about the same amount of calories as group B. The set-up of the experiment was the same as in the previous case. The results are also shown in Table 7 (Exp. 2).

It can be seen that mice on a diet restricted as to total amount and supplemented as to protein exhibit a higher degree of susceptibility to infection than mice of a non-supplemented group and a lower degree of susceptibility to infection than mice of the

Table 7. Relative susceptibility to Salmonella typhi murium infection of mice on specified diets

A, standard diet, ad libitum.

$\mathrm{B}$, standard diet, $60 \%$ of the amount of food consumed by $\mathrm{A}$.

C, standard diet in amount as B and protein-free supplement, ad libitum.

$\mathrm{D}$, high-protein diet, equal in amount to that of $\mathrm{B}$.

Experimental period: 5 weeks.

\begin{tabular}{|c|c|c|c|c|c|c|c|c|c|c|c|}
\hline \multirow[b]{2}{*}{$\begin{array}{l}\text { No. of } \\
\text { exp. }\end{array}$} & \multirow[b]{2}{*}{$\begin{array}{l}\text { Exp. } \\
\text { group }\end{array}$} & \multirow[b]{2}{*}{$\begin{array}{l}\text { No. of } \\
\text { mice* }\end{array}$} & \multicolumn{2}{|c|}{ Weight in $\mathrm{g}$. } & \multirow[b]{2}{*}{$\begin{array}{l}\text { No. } \\
\text { died } \dagger\end{array}$} & \multirow[b]{2}{*}{$\begin{array}{c}\text { No. } \\
\text { alive } \\
\text { and } \\
\text { cultured }\end{array}$} & \multirow[b]{2}{*}{$\begin{array}{c}\text { Total } \\
\text { in- } \\
\text { fected } \ddagger\end{array}$} & \multicolumn{4}{|c|}{ No. of mice with infections in } \\
\hline & & & $\begin{array}{l}\text { At start } \\
\text { of exp. }\end{array}$ & $\begin{array}{c}\text { At time } \\
\text { of } \\
\text { infection }\end{array}$ & & & & Liver & Spleen & $\begin{array}{l}\text { Liver } \\
\text { and } \\
\text { spleen }\end{array}$ & $\begin{array}{l}\text { Mesen- } \\
\text { teric } \\
\text { glands }\end{array}$ \\
\hline \multirow[t]{3}{*}{1} & A & 88 & $10 \cdot 5$ & $13 \cdot 5$ & 25 & 63 & $\begin{array}{c}22 \\
(33)\end{array}$ & $\begin{array}{c}12 \\
(19)\end{array}$ & $\begin{array}{l}12 \\
(19)\end{array}$ & $\begin{array}{l}10 \\
(16)\end{array}$ & $\begin{array}{c}22 \\
(35)\end{array}$ \\
\hline & B & 88 & $10 \cdot 5$ & $10 \cdot 3$ & 51 & 37 & $\begin{array}{c}30 \\
(81)\end{array}$ & $\begin{array}{c}20 \\
(57)\end{array}$ & $\begin{array}{c}19 \\
(51)\end{array}$ & $\begin{array}{c}15 \\
(41)\end{array}$ & $\begin{array}{c}23 \\
(63)\end{array}$ \\
\hline & $\mathrm{C}$ & 88 & $10 \cdot 5$ & $10 \cdot 9$ & 40 & 48 & $\begin{array}{c}28 \\
(58)\end{array}$ & $\begin{array}{l}14 \\
(31)\end{array}$ & $\begin{array}{c}13 \\
(27)\end{array}$ & $\begin{array}{c}9 \\
(19)\end{array}$ & $\begin{array}{l}26 \\
(54)\end{array}$ \\
\hline \multirow[t]{3}{*}{2} & A & 88 & $11 \cdot 3$ & $14 \cdot 9$ & 14 & 74 & $\begin{array}{c}38 \\
(51)\end{array}$ & $\begin{array}{c}23 \\
(31)\end{array}$ & $\begin{array}{l}18 \\
(24)\end{array}$ & $\begin{array}{c}14 \\
(19)\end{array}$ & $\begin{array}{c}28 \\
(38)\end{array}$ \\
\hline & B & 88 & $11 \cdot 2$ & $11 \cdot 0$ & 34 & 54 & $\begin{array}{c}47 \\
(87)\end{array}$ & $\begin{array}{c}34 \\
(63)\end{array}$ & $\begin{array}{c}34 \\
(63)\end{array}$ & $\begin{array}{c}31 \\
(57)\end{array}$ & $\begin{array}{c}44 \\
(81)\end{array}$ \\
\hline & $\mathrm{D}$ & 88 & $11 \cdot 3$ & $11 \cdot 5$ & 26 & 62 & $\begin{array}{c}40 \\
(64)\end{array}$ & $\begin{array}{c}30 \\
(48)\end{array}$ & $\begin{array}{c}28 \\
(45)\end{array}$ & $\begin{array}{c}27 \\
(44)\end{array}$ & $\begin{array}{c}32 \\
(52)\end{array}$ \\
\hline
\end{tabular}

* The one initially infected mouse in each cage is not included in these numbers.

$\dagger$ Cultures were made from the organs of 70 out of a total of 120 mice which died. In all the cases general in. fection with Salmonella was revealed.

$\ddagger$ The numbers in brackets show the percentage.

culture of S. typhi murium. Cultures were made from the liver, spleen and mesenteric glands of mice which died during the following fortnight. At the termination of this observation period all the survivors were killed and examined similarly. The results are summarized in Table 7 (Exp. 1). As is evident from this table, the mice on restricted food intake had a markedly higher rate of infection than control mice. Adequate supplementation of this restricted ration with protein-free food reduced the enhanced susceptibility, but did not nullify the effect of the restriction of the food consumption.

A second experiment in the same series was also carried out with litter-mates in three groups of ninety-four mice each. The groups were fed as control group. The increase in susceptibility exhibited by mice on the restricted diet has to be ascribed, therefore, to the combined effect of caloric and protein deficiency.

\section{DISCUSSION}

Our experiments show that the susceptibility of rats to Salmonella infection increases, if the food consumption of the animals is restricted. Two factors play a major role in this situation: the total duration of the period of the restriction of the food intake and the manner of the imposition of the restriction. When the food intake is held down to $80 \%$ of normal, resistance to infection is not affected after 
5 weeks, but appreciably lowered after 10 weeks. When the same total restriction is imposed in the form of a gradually reduced ration, the resistance of the animals is already markedly lowered after 5 weeks. Thus an equal total restriction of food intake appears to affect resistance to a far lesser degree when it is imposed in a uniformly reduced than when it is imposed in an increasingly reduced ration. This result seems to be independent of the percentage protein in the ration; increase of the dietary protein level did not change the susceptibility findings (Exp. 2), and, conversely, moderate restriction of the protein intake at constant level from the outset of the experiment did not in 5 weeks exert a deleterious effect on the resistance (Exp. 3). $\mathrm{Up}$ to a point the rat organism is apparently able to adapt itself to fixed restriction of its food ration. The adaptation fails, and the susceptibility rises, if this restriction is maintained for too long or is excessive in degree (Exp. 6). When, on the other hand, the same restriction of food intake is imposed in the form of a gradually reduced ration, this adaptation mechanism apparently does not become operative.

The question arises whether the breakdown of the infection resistance of the rat is due to either or both the caloric and protein restriction. Our experiments have shown that a sufficient caloric supply in a ration gradually restricted with respect to protein prevents only partially the lowering of the resistance to infection; increasing restriction of both calories and protein leads to lowering of resistance irrespective of the dietary protein level. On the other hand, gradually increased protein supplementation in a diet increasingly restricted as to calories leads likewise to a lowering of the resistance.

The experiments with mice, involving as they do a different species and an independent technique, complement the results of the rat experiments. Mice on a severely restricted fixed food ration showed a marked loss of resistance. Their susceptibility to epidemics was lessened by the supplementation of their diet with calories or protein. Caloric and protein deficiency together were, therefore, responsible for the increased infection susceptibility of mice on a restricted food ration.

It is noteworthy that protein supplementation of a caloric-deficient diet decreases the infection susceptibility of mice, but increases that of rats. The changes which dietary deficiency imposes on the protein and caloric economy of a growing animal are still speculative. The different nutritional needs of growing rats and mice suggest, however, a possible interpretation for our experimental data. Recently weaned rats and mice such as were used in the present work though they are equal in age differ from one another in growth rate. The weaned mouse gains $25-30 \%$ in weight in
2 weeks, whereas a rat of the same age gains $75-$ $90 \%$ in weight in the same time. The weight gain per g: of ingested food is also greater for the rat than for the mouse. Caloric deficiency sets up in both cases a situation in which dietary protein is used up as far as is possible for energy; but the rat, unlike the mouse, is still able on a diet $60 \%$ of normal to put on weight. In other words, a mouse on a similar caloric-deficient high-protein diet uses up dietary protein for energy to a far greater degree than does a rat. In consequence, the latter suffers on this diet to a more marked degree from caloric deficiency. Its enhanced susceptibility to infection in these conditions is probably a symptom of its greater caloric deficiency.

The biological mechanism underlying diminished resistance in protein deficiency has been studied by several investigators. Mills \& Cottingham (1943) found diminished phagocytosis in rats starved as to protein. They believe that this accounts for part of the loss of infection resistance which occurs in protein deficiency. Cannon and co-workers (1943, 1944), on the other hand, observed diminished ability to form antibodies to typhoid bacilli or sheep erythrocytes in rabbits and rats depleted of protein. Our own results, which will be published elsewhere, likewise point in this direction. We studied the response of rats in various nutritional conditions to intraperitoneal injection of S.typhi murium. In all the forms of nutritional deficiency investigated by us (caloric, protein, thiamine, riboflavin, or vitamin A deficiency), the bactericidal response of the peritoneal fluid was markedly diminished, but the phagocytic activity remained normal. It appears likely, therefore, that the diminution of resistance observed in our experiments was brought about by the lowering of the antibody response rather than by the reduced phagocytic activity.

\section{SUMMARY}

1. The effect of either or both caloric and protein deficiency on the susceptibility of rats and mice to peroral infection with Salmonella typhi murium was studied.

2. Moderate restriction of food intake $(80 \%$ of normal diet) for a period of 5 weeks was without influence on the infection susceptibility of rats, even when the diet fed was low in protein.

3. Long-term restriction of food intake ( 10 weeks) led to a marked lowering of the resistance of rats to the infection, there being a direct relation between the magnitude of the intake restriction and the extent of the resulting loss of resistance.

4. The infection resistance of rats was lowered more markedly by a given total restriction of food intake, when the latter was imposed in the form of a gradually reduced ration, than when it was im- 


\section{K. Guggenheim and Edith Buechler}

posed in a uniformly restricted ration. The effect so produced was independent of the protein content of the diet.

5. The effect of gradual food restriction was diminished by gradual supplementation of the diet with non-proteins and was augmented by gradual supplementation of the same diet with protein.

6. In mice kept on a restricted diet loss of resistance to $S$. typhi murium has been shown to be due to a deficiency of both calories and protein.

\section{REFERENCES}

Cannon, P. R., Chase, W. E. \& Wissler, R. W. (1943). Kuigler, I. J., Guggenheim, K. \& Henig, E. (1945). J. Immunol. 47, 133.

J. Hyg., Camb., 44, 61 .

Cannon, P. R., Wissler, R. W., Wooldridge, R. L. \& Benditt, E. P. (1944). Ann. Surg. 120, 514.

Kitgler, I. J., GugGenheim, K. \& Herrnheiser, H. (1946). J. Infect. Dis. 78, 60.

Guggenheim, K. \& Buechler, E. (1946). Proc. Soc. Exp. Biol., N.Y., 61, 413.

Mills, C. A. \& Cottingham, E. (1943). J. Immunol. 47, 503.

Kligler, I. J., GugGenheim, K. \& Buechler, E.

(1944). Proc. Soc. Exp. Biol., N.Y., 57, 132.

(MS. received for publication 19. Ir. 46.-Ed.) 